Journal of Teacher Education for Sustainability, vol. 20, no. 1, pp. 106-123, 2018

\title{
Assessing Teacher Competence and Its Follow-up to Support Professional Development Sustainability
}

\author{
Sumaryanta, Djemari Mardapi, Sugiman, and Tutut Herawan \\ Yogyakarta State University, Yogyakarta, Indonesia
}

\begin{abstract}
Teacher assessment has been recently considered as a minor issue in Education. Therefore, there is lacks teacher's competency assessment as the basis for the sustainability of teacher profession development. This study was on attempt to describe the model of teacher assessment which had been implemented in Indonesia and its challenges to encourage the development of a sustainable teacher profession. The data was collected through documentation. Moreover, some interviews were conducted about (1) teacher competency test in 2012-2014 by 1,611,251 teachers; in 2015 by 2,699,516 teachers, and in 2016 by 427,189 teachers, and (2) teacher development programs as a follow-up of teacher competency tests. The obtained data was analized by descriptive quantitative and qualitative, respectively, on the document study result data and the interviews. The teacher competency test results were used to measure the mastery of pedagogic and professional competence of teachers at all subject matter and all levels of schools in Indonesia. Furthermore, the results are used as the basis for determining teacher quality improvement program in Indonesia continuous training. They are expected to provide best practice information from the implementation of teacher competency mapping done in Indonesia including its follow-up in order to develop the teacher's sustainable profession.
\end{abstract}

Keywords: teachers, assessment, sustainable profession development

\section{Introduction}

Teacher assessment is still a minor issue in educational assessment. Discussion on the assessment recently is dominated by focusing on the assessment of student achievement. In fact, an assessment of the competence and performance of teachers are as important as the teaching task itself (Darling \& Hammond, 2010). Teachers are the key factors that influence the success or failure of the student learning. Besides, being important in the context of classroom learning, teachers also play an important role in social transformation (Okeke \& Mtyuda, 2017). The teacher's central position in student learning must be balanced with sustained teacher quality monitoring.

The teacher's assessment is not only to know the extent to which teachers master the taught material, but also to encourage self-sustained teacher development (Wilkerson \& Lang, 2007). The results of this assessment are also useful for the purposes of decision 
making in teacher coaching. The resulting program is based only on assumptions and speculative analysis often mismatch and misdirected, which at the end will only result in failure. In contrast, teacher coaching programs that are preceded by competency mapping, which are further analyzed as the basis of the program, are expected to be more effective and efficient.

Internationally, there has been an increasing interest in assessing teacher competence driven by demand for quality assurance and greater recognition of the teaching profession (Roelofs \& Sanders, 2007; Vermunt \& Verloop, 1999). Teachers, increasingly, have been accepted as a profession that has a vital position and role in the development of human life as the more awareness of the role of education in human development. Awareness rising on the importance of teacher roles implicates higher demands on teacher quality. The assessment of teacher competencies serves as a way to know how great the quality of teachers.

Various countries, including Indonesia, have conducted teacher competency tests (TCT) as part of the teacher competency mapping process. For a country with a very large number of teachers, such as Indonesia with almost 3 million teachers, performing competency assessments (PCA) and TCT are not easy tasks. The next challenge is not only on the implementation of assessment which is not easy, but also on how to followup the results of the PCA and TCT. In the massive TCT, technical implementation of tests for a large number of teachers, analysis of test results, and the formulation of follow-up test results are complex tasks.

The Government of Indonesia has made a major program in assessing teacher through Teacher Competency Test (TCT). The TCT is conducted to measure the mastery of pedagogic competence and professional teachers. The TCT have been massively implemented since 2012 and continue up to now. In 2014, there are 1,611,725 teachers who have assessed through TCT. Subsequantially, in the year 2015 there is nationwide TCT followed by 2,699,516 teachers in Indonesia.

This study was intended to describe the teacher competency test model that is implemented nationally in Indonesia through TCT along with the results and its followup to develop and implement the teacher competency improvement program. This study reveals on how the competency test model that has been implemented in Indonesia, how the results obtained, and what follow-up of the competency test results in improving the quality of teachers. More specifically, the research questions addressed through this study are given as follow:

1) What are the objectives of the teacher competence test?

2) What are the competencies measured in the teacher competence test?

3) What kind of questions are used for the teacher's competency test?

4) How to implement the teacher competency test?

5) What is the result of teacher competence test?

6) How is the teacher competency test in the context of teacher professional development?

7) What kind of program for follow-up teacher competence test that has been implemented?

8) What is the outcome of the follow-up program in improving teacher competence?

The results of this study are expected to provide best practice information on the implementation of teacher competency mapping conducted massively, as well as its follow-up for the development of teacher profession. 


\section{Literature Review}

The continuing education is not an option but a necessity to address the challenges of growing human needs (Donaldson et al., 2013). Teachers, as a key component of education, face new challenges and changes that require them to equip themselves with new knowledge and skills (Kabadayi, 2016). Professionalism of teachers must be run in accordance with the development of science, technology, art, and progress of society and era (Mulyasa, 2013). Teachers who continue to learn are an essential component for the realization of continuing education as a catalyst to build human civilization in a better direction.

The assessment of teacher performance competency and evaluation should be conducted in a way to improve teacher performance. The assessment of teacher competence is not only to determine the extent to which teachers master the taught material but also encourage self-development of teachers (Wilkerson \& Lang, 2007, p. 17-18). Evaluation of teachers tasks can: (1) improve teachers' performance in performing professional duties (improvement function); and (2) ensure teachers to perform better in learning development of students (accountability function) (OECD, 2009). Without assessment and evaluation on the performance of the task, the teacher will be less motivated in learning and developing. In fact, only from teachers who continue to learn will emerge a generation of learners throughout life who are able to continue to contribute to society and the environment.

The mapping of teacher competence and performance can be conducted in various ways, including: Test, training record, performance observation, portfolio, product, and learner work example (Wilkerson \& Lang, 2007). For mapping teacher competencies in a broad scope, e.g. nationally, tests are a better alternative. Tests can be conducted to capture the picture of teacher competence in large numbers. Standardized tests will provide accurate and accountable assessment results.

The assessment of teacher competencies requires a clear definition of what competencies are assessed to guide evidence collection and assessment (Roelofs \& Sanders, 2007). Although in general people already have perceptions about the meaning of competence, but really competence is a broad and diverse terminology (Vathanophas, 2007). Experts interpret the competence of teachers in various ways. Teacher competence is an accumulation of capabilities to facilitate learning (Carreker \& Boulware, 2015). Teacher competence refers to performance and rational action to meet certain specifications in the task of education (Mulyasa, 2007). Teacher competence is a multi-dimensional construct, not only of pedagogical competence but also of professional competence (Baumert \& Kunter, 2006). Teacher competence includes: pedagogical competence, subject-didactic competence, pedagogical-organizational competence and self-reflection competence (Hospesová \& Tichá, 2000), while Redding (Reeding, 2014) and Carreker \& Boulware (Carreker \& Boulware, 2015) stated that there are four personal competence of teachers, namely: Cognitive competence, metacognitive competence, motivational competence, and emotional / social competence. Many of the scope of these competencies require careful determination of the focus of assessment in assessing teacher competency.

The competency map of the assessment results is needed as the basis for the preparation of teacher quality improvement program that is teacher training program. Training that is designed without accurate data often does not meet the needs (Silberman, 2006). Many programs are implemented without a clear needs analysis (Goldstein \& Ford, 2002: 10). This then became the cause of much ineffective teacher training. 
The competence-based training is currently increasingly popular among educational stakeholders (Acquah et al., 2017). Competence-based training has been adopted for teachers to improve their competence. The adequacy of teacher participation in training activities is essential for professional development (Zineb et al., 2017). Through training activities, teacher competencies that have not met the standards can be improved. Teachers' competence test becomes very important in the context of providing data for the preparation and implementation of training programs as per the needs of teacher sustainable development.

\section{Method}

This study was a descriptive one aimed to describe the implementation of national teacher assessment by teacher competency test (TCT) in Indonesia and its follow-up in supporting of the sustainability of professional development. This study was conducted in Indonesia in September 2017 until April 2018. The research was conducted on: (1) the implementation of teacher competency test in $2012-2014$ by 1,611,251 teachers, in 2015 by 2,699,516 teachers, and in 2016 by 427,189 teachers, and (2) the implementation of teacher competency development program and its follow-up teacher competency test conducted by the Indonesian government in 2016. The data of this study were collected through documentation and interview study. The documents reviewed in this study were documents on teacher competence test results and the TCT follow-up teacher competence development program from the Indonesian government through the Directorate of Teachers and Education Personnel of the Ministry of Education and Culture, Republic of Indonesia. Interviews were conducted with teachers from various provinces in Indonesia as participants of teacher competency tests, as well as trainers and national speakers of teacher training. The obtained data is analyzed by descriptive quantitative and qualitative, where quantitative analysis is done on document study result data, meanwhile qualitative analysis is done on interview result data.

\section{Results and Discussion}

The national TCT in Indonesia is a program launched by the government in order to ensure that Indonesian teachers are qualified (Ministry of Education and Culture, 2015). The TCT is implemented with the aims of: (1) obtaining information on teacher competency figure, especially pedagogic and professional competence in accordance with predetermined standard; (2) obtaining a teacher competency map that will be considered in determining the type of teacher education and training; and (3) assessing the performance of teachers and be considered for policy formulation to give appreciation and appreciation to teachers.

The TCT in Indonesia is not just a project that is implemented without reason and a strong base of thought. The TCT is born as a result of contemplation and long thinking taps the journey of Indonesian nation in managing education. The experience and achievement of the quality of education in Indonesia until now has not been full of encouragement, thus encouraging the government to issue various policies to improve education. The TCT is an instrument in an effort to improve the quality of teachers in Indonesia.

The TCT is conducted to measure basic competence on subject matter and pedagogy in content domain (Ministry of Education and Culture, 2015). The basis for the prepar- 
ation of TCT is the Regulation of the Minister of National Education Number 16 Year 2007 regarding Academic Qualification and Teacher Competency Standards (Table 1). The competence of the field of study is tested according to the field of study of each teacher. The pedagogical competence tested is the integration of the pedagogic concept into the learning process of the field of study in the classroom.

Table 1

Indonesian Teachers Competency Standards

\begin{tabular}{ll}
\hline Aspect & \multicolumn{1}{c}{ Teacher Competency } \\
\hline Pedagogic & - Mastering the characteristics of learners, such as physical aspects, moral, \\
Competency & spiritual, social, cultural, emotional, and intellectual. \\
& - Mastering learning theories and principles of educational learning. \\
& - Develop a curriculum related to the subjects taught. \\
& - Organize educational learning. \\
& - learning. \\
& - Facilitate the development of potential learners to actualize various potentials. \\
& - Conmunicate effectively, empathically, and well mannered with learners. \\
& - Utilizing assessment and evaluation results for learning purposes. \\
- Reflective take action to improve the quality of learning
\end{tabular}

The competence of the teachers above is breakdown into indicators of achievement of competence (GPA). Based on this GPA the further items about the TCT are prepared. The TCT was in the form of multiple choices of 4 options amounted to 60-100 items worked on for 120 minutes. The TCT is implemented using two systems i.e. online system and offline system. The online system is implemented on an affordable area of the internet network, and has a room that contains computer lab devices, and is connected within an intranet network. Offline or manual systems are implemented in areas not covered by the internet network, and do not have rooms containing computer labs, and are not connected in the internet (Ministry of Education and Culture, 2015). Of the two systems, most of the TCT implementation uses an online system. Offline systems are implemented in a limited area only in areas that are really difficult to implement online.

The TCT becomes one instrument of continuous professional development (CPD) of the teacher in Indonesia (Ministry of Education and Culture, 2016). The CPD of the teacher in Indonesia is the development of teacher competencies that are carried out in accordance with the needs, gradually, sustained, to improve the professionalism of teachers. The CPD of the teacher is part of various efforts to improve the competence of teachers, includes: planning activities starting from the results of self-evaluation, TCT, and PCA by the Principal and/or school assessment team on the implementation of learning in classroom and other tasks (Ministry of Education and Culture, 2016). 

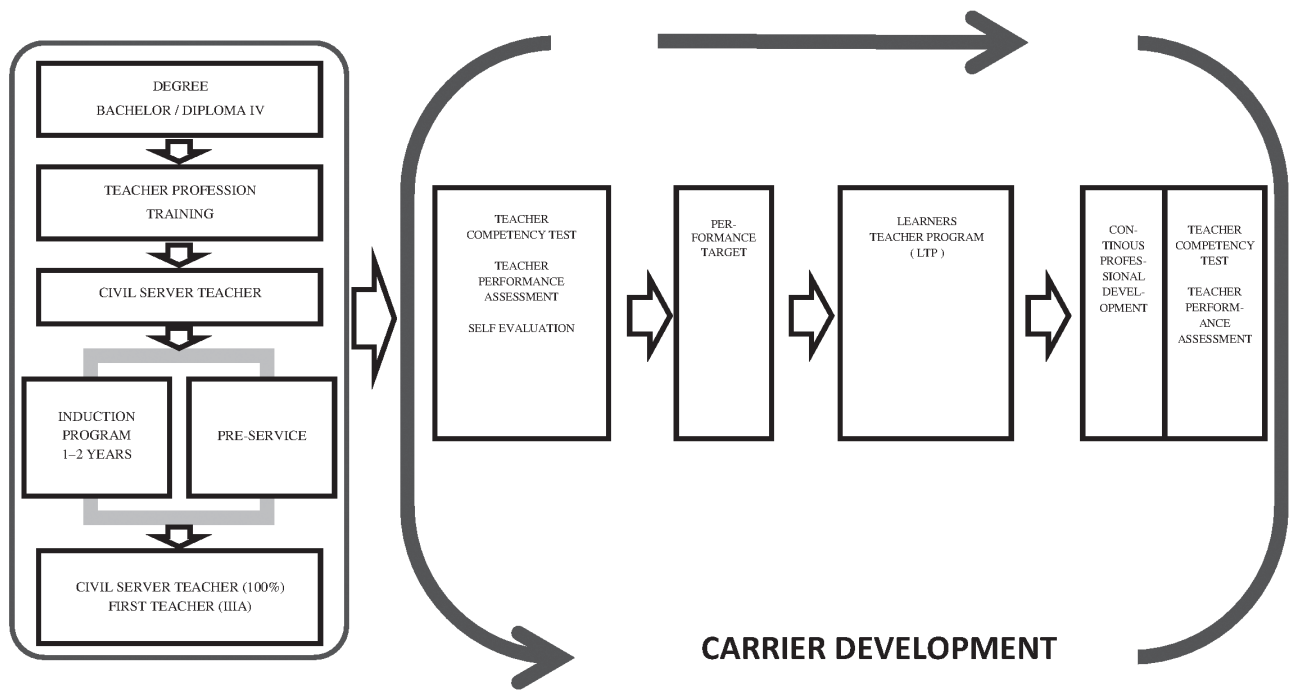

Figure 1. Teacher career development scheme (Ministry of Education and Culture, 2016)

Figure 1 shows that TCT is a key component in teacher career development. The TCT is part of teacher development that is to identify teacher's competency profile, as a basis for guidance and self-development of teachers. The teacher career development process is conducted simultaneously and sustained, whose level of achievement is identified through TCT again. The new results of the TCT are then used as the basis for further guidance and teacher development.

The TCT is implemented nationally in 2014 and 2015. Until 2014 the number of teachers who have followed the TCT is as many as $1,611,725$ people. The analysis on TCT results shows a portrait concerning the competence of teachers nationally as shown in Table 2. The average of TCT score (2012-2014), which is 46.55 as shown in Figure 2.

Table 2

TCT Result (2012-2014)

\begin{tabular}{cccccccc}
\hline Scores & $\begin{array}{c}\text { Kinder- } \\
\text { garten }\end{array}$ & $\begin{array}{c}\text { Primary } \\
\text { School }\end{array}$ & $\begin{array}{c}\text { Junior } \\
\text { High School }\end{array}$ & $\begin{array}{c}\text { Special } \\
\text { School }\end{array}$ & $\begin{array}{c}\text { Senior } \\
\text { High School }\end{array}$ & $\begin{array}{c}\text { Vocational } \\
\text { High School }\end{array}$ & Total \\
\hline $0-10$ & 83 & 822 & 527 & 5 & 349 & 89 & 1,875 \\
\hline $10.1-20$ & 176 & 4,300 & 1,068 & 28 & 1,620 & 460 & 7,652 \\
\hline $20.1-30$ & 3,956 & 86,175 & 14,631 & 834 & 13,677 & 5,652 & 124,925 \\
\hline $30.1-40$ & 19,538 & 268,408 & 57,204 & 3,099 & 35,822 & 21,298 & 405,369 \\
\hline $40.1-50$ & 44,094 & 264,138 & 96,833 & 4,333 & 50,293 & 35,833 & 495,524 \\
\hline $50.1-60$ & 57,025 & 132,537 & 86,453 & 2,377 & 45,375 & 32,791 & 356,558 \\
\hline $60.1-70$ & 36,824 & 37,478 & 49,141 & 652 & 26,132 & 17,469 & 167,696 \\
\hline $70.1-80$ & 8,693 & 4,733 & 18,534 & 74 & 8,901 & 5,072 & 46,007 \\
\hline $80.1-90$ & 452 & 188 & 2,930 & 4 & 1,225 & 654 & 5,453 \\
\hline $90.1-100$ & 3 & 57 & 92 & - & 24 & 16 & 192 \\
\hline Total & 170,844 & 798,836 & 327,413 & 11,406 & 183,418 & 119,334 & $1,611,251$ \\
\hline
\end{tabular}

Source: Ministry of Education and Culture, 2015 


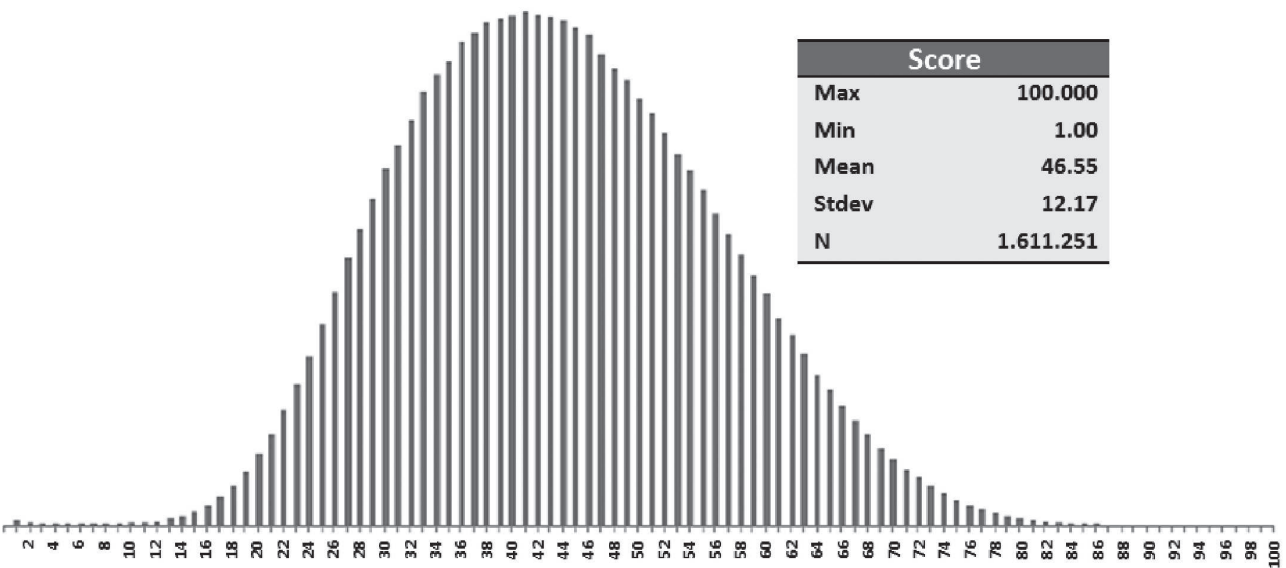

Figure 2. Distribution of the teacher score, TCT 2012-2014

Source: Ministry of Education and Culture, 2015

The results of TCT until 2014 became the basis for determining the target of teacher competency improvement by National Development Planning Agency in 2015-2019. The agency targeted from 2015 to 2019 a gradual increasing in teacher competence, as shown in the following Table 3.

Table 3

Target of Teacher Competency Improvement in 2015-2019

\begin{tabular}{cc}
\hline Years & Target of teacher competency score \\
\hline 2014 (Baseline) & 46.55 \\
\hline 2015 & 50.50 \\
\hline 2016 & 60.50 \\
\hline 2017 & 70.00 \\
\hline 2018 & 70.50 \\
\hline 2019 & 80.00 \\
\hline
\end{tabular}

Source: The Strategic Plan of the Directorate of Teachers and Education Personnel 2015-2019

From Table 3 above, the target of teacher competency score is measured by TCT. The results of the TCT are, then, used to determine the participation of teachers in the program of competence improvement that has been prepared by the government, so that cyclic is expected to occur the flow of mapping and improvement of competence simultaneously and sustained. The following up of the National Development Planning Agency program / target, the Indonesian Ministry of Education through the Directorate of Teachers and Education Personnel in 2015 implemented a TCT training program, the Post-TCT Training Program. It is one of the program that is expected to encourage the improvement of teacher competence.

Furthermore, by 2015 the government implemented TCT for almost all teachers in Indonesia. A total of 2,699,516 teachers, including kindergarten, elementary, junior high school, junior high school, and vocational high school teachers have attended TCT in 2015, with details as listed in the following Table 4. 
Table 4

Teacher Data of TCT Participants in 2015

\begin{tabular}{clc}
\hline No & \multicolumn{1}{c}{ Level } & Total \\
\hline 1. & Kindergarten & 252.631 \\
\hline 2. & Primary School & 1.389 .859 \\
\hline 3. & Special School & 21.287 \\
\hline 4. & Junior High School & 561.164 \\
\hline 5. & Senior High School & 254.166 \\
\hline 6. & Vocational High School & 220.409 \\
\hline & & Total \\
\hline
\end{tabular}

Source: Directorate of Teachers and Education Personnel, 2015

The result of TCT in 2015 shows the national average is 56.69. It exceeds the target of achieving the national average value of 2015 set in Ministry of Education and Culture strategic plan, which is 55. Meanwhile, from the aspect of competence, the average achievement of the pedagogy competency 52.37, and average achievement of the professional competence score 58.55 (Ministry of Education and Culture, 2016). In more detail, the 2015 TCT results are presented in Table 5.

Table 5

Results of TCT Year 2015

\begin{tabular}{cccccccc}
\hline Score & $\begin{array}{c}\text { Kinder- } \\
\text { garten }\end{array}$ & $\begin{array}{c}\text { Primary } \\
\text { School }\end{array}$ & $\begin{array}{c}\text { Junior } \\
\text { High School }\end{array}$ & $\begin{array}{c}\text { Senior } \\
\text { High School }\end{array}$ & $\begin{array}{c}\text { Vocational } \\
\text { High School }\end{array}$ & $\begin{array}{c}\text { Special } \\
\text { School }\end{array}$ & Total \\
\hline $1-10$ & 24 & 280 & 157 & 46 & 59 & 2 & 568 \\
\hline $11-20$ & 89 & 1,074 & 715 & 295 & 179 & 12 & 2,364 \\
\hline $21-30$ & 1,096 & 28,659 & 10,805 & 4,371 & 2,708 & 242 & 47,881 \\
\hline $31-40$ & 9,652 & 183,896 & 54,381 & 19,791 & 18,200 & 1,719 & 287,639 \\
\hline $41-50$ & 35,908 & 330,638 & 108,252 & 39,095 & 42,404 & 3,901 & 560,198 \\
\hline $51-60$ & 77,816 & 405,946 & 140,843 & 54,438 & 58,710 & 6,428 & 744,181 \\
\hline $61-70$ & 94,774 & 278,257 & 129,623 & 59,486 & 57,970 & 5,708 & 625,818 \\
\hline $71-80$ & 30,522 & 125,991 & 77,657 & 45,623 & 29,896 & 2,734 & 312,423 \\
\hline $81-90$ & 2,721 & 31,104 & 32,900 & 24,095 & 9,380 & 501 & 100,701 \\
\hline $91-100$ & 29 & 4,014 & 5,831 & 6,926 & 903 & 40 & 17,743 \\
\hline Total & 252,631 & $1,389,859$ & 561,164 & 254,166 & 220,409 & 21,287 & $2,699,516$ \\
\hline
\end{tabular}

Source: Directorate of Teachers and Education Personnel, 2015

The results of the TCT are, then, processed based on various aspects, by region, school level, subject, age and gender of teachers, and others as needed. These processed data are, then, used to formulate policies for the development and development of teacher competence, both at the national and regional levels. The results of TCT can be used as the basis for developing teacher quality improvement program at school level, even individually by each teacher.

Based on the results of the TCT, each teacher receives a competency map that is mastered in the form of a report book of each teacher. The teacher report book presents the achievement data of each teacher of TCT result as stated in 10 Groups of Competency (GC) i.e. GC-A, GC-B, GC-C, GC-D, GC-E, GC-F, GC-G, GC-H, GC-I, and GC-J. 
Each GC contains a set of pedagogical competencies and professional competencies. The contents of pedagogical and professional competencies in the teacher report book vary for each different subject. Hence, this is tailored to the teacher's competency demands based on the subjects taught. The individual teacher report book is presented graphically, an example of a teacher report book is shown in the following Figure 3.

\begin{tabular}{|c|c|c|c|c|c|}
\hline \multicolumn{6}{|c|}{ Your Module Groups } \\
\hline No. & Group of Competency & Status & & & Status \\
\hline 1 & Mathematic GC-A & PASSED & 6 & Mathematic GC-F & FAILED \\
\hline 2 & Mathematic GC-B & FAILED & 7 & Mathematic GC-G & PASSED \\
\hline 3 & Mathematic GC-C & PASSED & 8 & Mathematic GC-H & FAILED \\
\hline 4 & Mathematic GC-D & PASSED & 9 & Mathematic GC-I & PASSED \\
\hline 5 & Mathematic GC-E & PASSED & 10 & Mathematic GC-J & PASSED \\
\hline
\end{tabular}

Figure 3. Examples of teacher report books on mathematics subjects

The teacher report book is presented in red and black. The red color indicates that in the competence group the teacher has not reached the minimum standard of competence that the teacher must master. The black color indicates that in the competence group the teacher has reached the established competency. Minimum standards used as teacher completion limits are set nationally for each year according to the competency targets established during the current year: 2015 standards 5.5, 2016 standards 6.5, 2017 standards 7.0, 2018 standards 7.5, and 2019 standard 8.0. This means, for example, that by 2017 the attainment of teacher competence in a competence group of 67 , then the report book on the competence group is red. In other competence groups, for example, the teacher obtained 81, and then the report book on the competence group is black. Further teacher report books serve as the basis for providing follow-up programs for individual teachers to improve the teacher's competence.

From the interviews, the feedback is very positive. The results of the TCT in the form of reports given to each teacher are considered to have significance for the teacher. Based on the acknowledgment of several teachers of interview respondents of this study who said that the report on the results of TCT in the form of individual reports of teachers remind teachers about the level of mastery of competencies controlled by the teacher. Based on these reports the teacher knows which competencies are by default met by and which do not meet the standards. It is as said one respondent named Karim as follow:

TCT has been done by the government has succeeded in showing the level of mastery of teacher competence which during this time teachers never know how the level of control of competence. During this time when learner learning outcomes are less satisfactory then the focus of attention of the teacher more toward how to motivate and improve learner learning performance. At the 
time of the TCT report submitted to the teacher, the teacher becomes aware that there is a problem in the mastery of competence which explains why the teaching performance is not optimal. (Karim, Teacher from East Kalimantan Province, Interview: April 11, 2016).

Wakhidul Karim's remarks are in accordance with the statement of another teacher, Supriatin, who stated that:

When the government informs that there will be a competency test for all teachers, the teacher tries to prepare by reading relevant references. Discussions at the teacher community level are also conducted among teachers to discuss materials related to teacher competence. After the TCT is implemented, and the teacher receives a report showing the test results, the teacher then understands that there are competencies that must be mastered by the teacher according to established standards, which have not been mastered by the teacher. In the future, teachers who have not met the competency standards are required to attend training in improving the competence of teachers, the teachers follow well in the hope of improving the competence (Supriatin, Teacher/National Trainer from West Java Province, Interview: April 11, 2018).

In 2016, the government launched a follow-up policy on TCT results through the Learners' Teacher Competency Enhancement Program (LTCEP) (Figure 4). The LTCEP is a learning activity for teachers through training in order to improve the ability and competence of teachers in performing professional duties. The upgrades include activities aimed at improving and growing abilities, attitude, and skills (Ministry of Education and Culture, 2016). From this activity is expected to produce a change of behavior of teacher which is real change of behavior have an impact on improving teacher performance in learning process in classroom.

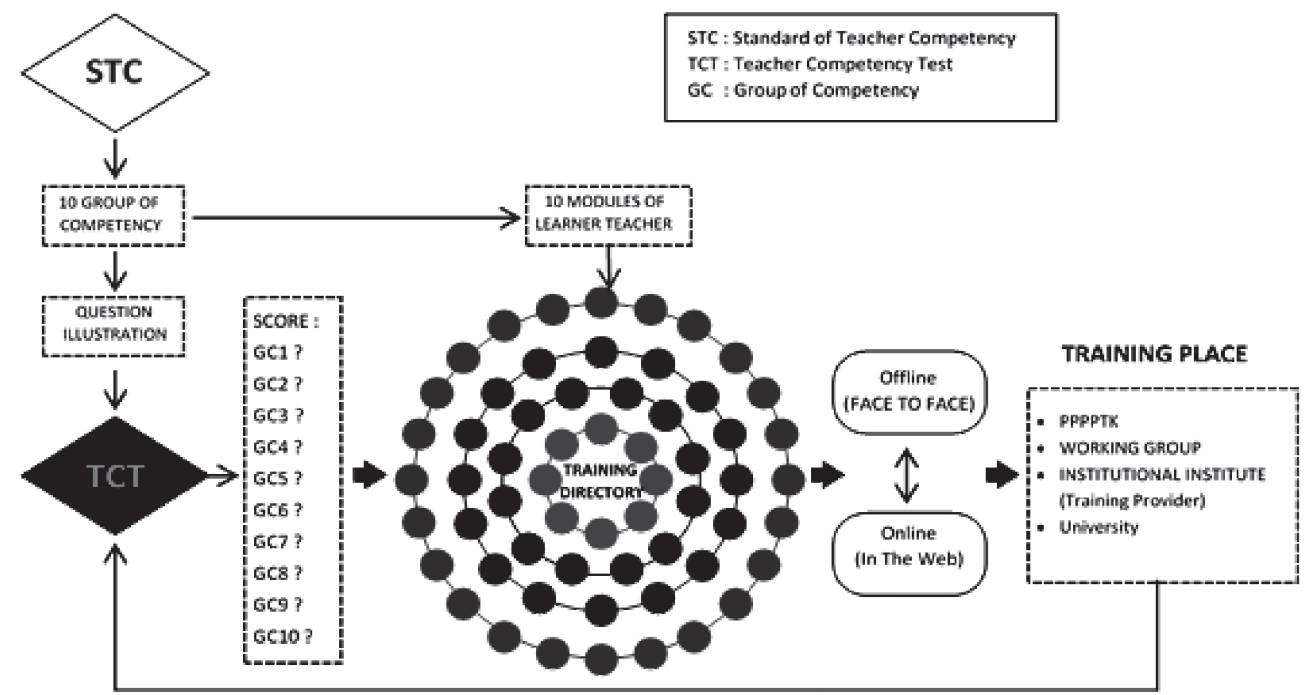

Figure 4. LTCEP flow

Source: Directorate of Teachers and Education Personnel, 2016 
The LTCEP is developed based on teacher competency standards before being used as a basis for the preparation of TCT questions. This is in line with the purpose of the learners' teacher program which is oriented as a follow-up of TCT results. Based on the Competency Achievement Indicator (GPA) in Standard of Teacher Competency (STC), a teacher competency map is developed which is divided into 10 competency groups. Furthermore, from 10 groups of competencies, a module of learners' teacher competency improvement is developed for each group of competencies. These modules will furthermore be used learning materials for teachers who have not yet achieved competence in the appropriate competence groups. The LTCEP is conducted through three modes i.e. the Facial Face, Online, and Combination of both.

1) Face-to-face Mode

The face-to-face mode is for teachers who need a more intensive upgrading of competencies by studying 8-10 modules. In addition, to provide learning options for teachers who do not have enough choice due to various limitations, so it is not possible to follow other learning mode, for example due to geographical reasons, the lack of / lack of electricity and internet network, the availability of budget, information technology literacy and communication, as well as other rational reasons.

2) Online mode

Online mode is for teachers who need to improve their competence by studying 35 modules. Online mode can be implemented by preparing a learning system that independently provide instruction and learning services to the participants without directly involving the teacher in the process of organizing. The instructional system includes the registration process, the implementation of learning, the final test, and the determination of the passing of the participants and the issuance of certificates. In some cases, the involvement of a capability is still required, e.g. in checking and assessing tasks that the system cannot yet implement, or to assist the participants in case of difficulties that the system has not been able to address.

3) Combination

Combination mode is intended for teachers who require increased competence by studying 6-7 modules. Combination mode online is a mode that combines face to face with online. Facilitators on the one hand can be represented by a learning system consisting of firmware, brain-ware, and software; and participants on the other hand carry out the instructions given by the system, start registration, implementation of learning, up to evaluation. The involvement of mentors can be done in 2 (two) ways: (1) meet face to face with the participants; or (2) face to face virtually, either through video, audio, or text.

If there are obstacles, then the 3 modes are not possible, teachers still have to improve their competence by doing self-learning. From the interviews, the feedback is very positive. The above TCT results-based training is considered as an appropriate strategy. This is revealed by the results of interviews with national speakers of training as follow:

Training conducted in accordance with the need for teacher competency improvement, based on the results of TCT, can run more effectively, than in general training, conducted without an accurate basis. Teachers with conditions have not mastered the same competence, and then given the same training in accordance with the competence that still not meet the standard, make it easier also in the implementation of the lesson during the training. 
Competencies that are taught are also more focused on certain competencies that seem to be lacking (Purnomo, National Trainer, interview: April 16, 2018).

Training by offline and online modules is an appropriate training strategy, especially for large targets and diversity of teacher abilities. This is stated by one respondent of this study, named Khikmawati, as follows.

Module-based training is a training strategy that is quite relevant to the needs. Teachers, who have not mastered certain competencies, are included in appropriate training, with the need for less competence, and facilitated learning through modules that contain materials that can improve competence. The broad range of competencies is not possible to teach all through training. Modulefacilitated teachers can learn more independently about the competencies not taught during the training. Implementation of online training is also appropriate, especially to answer the needs of training that is mass. Online training constraints that are sometimes caused by ICT literacy can be overcome by a combined pattern, an online-offline combination. When offline, teachers are taught the training systems and applications used, as well as the general overview of the training, which teachers then study independently by utilizing prepared online modules. (Khikmawati, National Trainer, Interview: April 11, 2016).

Throughout the year 2016, the number of teachers who participated in the LTCEP is 427,189 or $15.82 \%$ of $2,699,516$. The percentage of teachers' participation in the $15.1 \%$ LTCEP does not yet describe the total teacher population, however, it provides a glimpse of the results of facilitation provided to teachers in the Learners' Teacher Competency Enhancement Program. The average 2015 TCT Results with TCT 2016 can generally be illustrated in Table 6 .

The distribution of TCT values for each level is shown in Table 7.

Table 6

Average Score of TCT Year 2016

\begin{tabular}{lccc}
\hline \multicolumn{1}{c}{ Aspect } & TCT 2015 & TCT 2016 & Improvement \\
\hline National Mean & 39.48 & 64.92 & 25.44 \\
\hline Pedagogic Mean & 41.87 & 63.79 & 21.91 \\
\hline Professional Mean & 38.46 & 66.05 & 27.59 \\
\hline Participants & 427.189 & 427.189 & \\
\hline
\end{tabular}

Source: Directorate of Teachers and Education Personnel, 2016

Table 7

Distribution of TCT Score Year 2016

\begin{tabular}{lccccc}
\hline Level & Participants & Person/Module & Mean 2015 & Mean 2016 Improvement \\
\hline Kindergarten & 72.016 & 141.522 & 43.32 & 65.82 & 22.49 \\
\hline Primary School & 219.207 & 432.416 & 40.17 & 63.80 & 23.63 \\
\hline Special School & 3.310 & 6.602 & 40.82 & 66.79 & 25.97 \\
\hline Senior High School & 85.390 & 170.155 & 35.46 & 65.33 & 29.87 \\
\hline Senior High School & 27.847 & 47.151 & 38.07 & 66.66 & 28.59 \\
\hline Vocational High School & 19.390 & 170.155 & 35.46 & 65.33 & 29.87 \\
\hline
\end{tabular}

Source: Directorate of Teachers and Education Personnel, 2016 
The results of the program learners' teacher in 2016 then followed through the program continued in 2017. Currently the results of the program in 2017 are still being analyzed, as well as the preparation of the program continued in 2018. Sustained expected government targets that the year 2019 average Indonesian teacher competence to reach 8.0 can be achieved.

\section{Implications}

Discussion on the assessment of education is mostly done on the assessment of learning outcomes, while the assessment on the competence of teachers is still rarely done and discussed. This is noteworthy, because assessment of teachers is also important as part of their performance evaluation (OECD, 2009). Emphasis on competency-based training also increases the need for teacher competency assessments (Roelofs \& Sanders, 2007, p. 124). The results of this assessment are also useful for the purposes of decision making in teacher coaching. Accountability in the teaching profession can also be obtained through assessments of teacher competence.

The effectiveness measurement of teacher performance is as important as the development of the teacher itself (Darling \& Hammond, 2010, p. 12). Therefore, the perspective on the teacher should not be focused only on the learning achievement of learners, but also on mastering the competence by teachers. Not only students who need to be assessed learning outcomes, teachers also need to be measured mastery of the competencies that their provision of teaching in the classroom. If the competence of teachers is low, then the teacher may confront difficulty to provide educational services to students. If the results of the assessment show that students have not been able to master the competencies taught by the teacher, then the teacher performs certain steps to improve the student's competence. Similarly, if the results of the assessment indicate that the mastery of their competence is low, it is necessary to improve the quality of teachers.

The policy to encourage teachers to become learners is a strategic step to encourage teachers to develop self-employment in a sustained manner. The development of sustained proficiency for each teacher demands the commitment of each teacher (Brine, 2005). The learners' teacher program, which in essence encourages teachers to raise awareness and commitment to continue learning, becomes an appropriate vehicle for sustained teacher self-development. Learners' teacher is a teacher who is committed to continuing to study as long as she devotes herself to education. Therefore, when a teacher decides to quit or does not want to learn, then at that time he stops being a teacher or educator.

The mapping teacher competence is important because teachers are one of the most dominant factors affecting the success of education. Hattie (2013, p. 3) shows that teachers are a dominant factor affecting student achievement. Teachers contribute $30 \%$ influence on student achievement and the rest student contributes $50 \%$, home contributes $5-10 \%$, school contributes $5-10 \%$, peer effects contributes $5-10 \%$, and principal contributes less than $5 \%$ as described in Figure 5. 

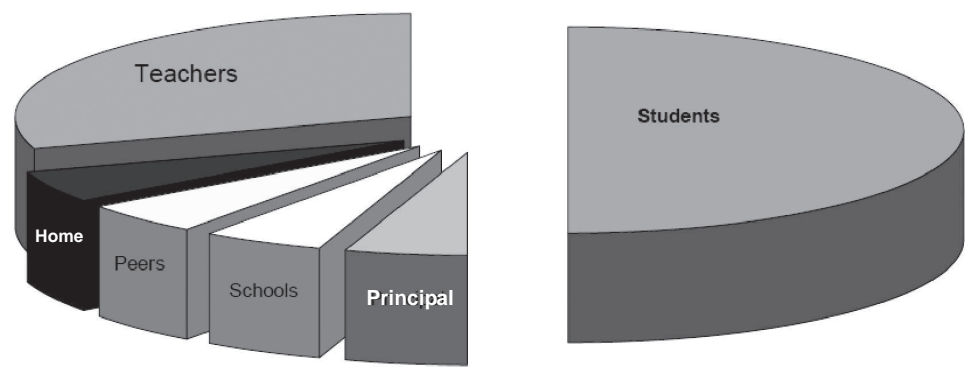

Figure 5. Percentage of achievement variance students (Hatie, 2003)

This is in accordance with the opinion (Cobb \& Hodge, 2002) which states that teachers are the most important source for developing a student's mathematical identity. They influence the ways in which students' think of themselves in the classroom (Anthony and Walshaw, 2009; Walshaw, 2004). Therefore, the success of learning mathematics school can be determined by the quality of mathematics teachers, both in terms of mastery of mathematical materials and teaching methods. How much the influence percentage of teachers on student achievement as seen in the Figure 6 above shows that programs that encourage teacher quality improvement should be considered as a serious concern. Accurate data is needed as a basis for the preparation of teacher quality improvement program so that the teacher really get the program service as needed. What competencies need to be improved from the teacher should be well identified, in which the low level of competency is the focus of teacher development. After implementing the TCT, the Indonesian government launched a teacher competency development program through the Learner Teacher Training Program in 2016. The follow-up of TCT through the learners' teacher program implemented in the form of training is the right policy in improving teacher competence. The process of realizing a professional teacher can be done through training (Iswari, 2019, p. 111). Training is important for teachers in schools as a tool for professional development and to improve the knowledge and quality of teaching and learning for sustained education (Kabadayi, 2016, p. 12). Research Kunartinah and Sukoco (2010: 83) resulted in the finding that education and training have a positive and significant impact on competence. The research of Hasanah (2010: 85) show that the influence of teacher education and teacher training on teacher performance (X1 on $\mathrm{Y}$ ) is $33 \%$, while work climate factor on teacher performance (X2 on Y) is $67 \%$. Simultaneously the educational factors and teacher leadership training with work climate (X1 and $\mathrm{X} 2$ on $\mathrm{Y}$ ) is $57 \%$. The results of this study show how great the contribution of training is in supporting the improvement of teacher performance. The Teachers' Training Programs Learners are designed to be TCT-based outcomes and implemented as a followup to improving under-standard teacher competencies. Through the training is expected to produce teachers of learners, namely teachers who continue to learn and develop (upgrade) themselves at anytime and anywhere. The TCT follow-up policy, in improving teacher competence through training, is a very appropriate policy, in the context of accurate teacher-based development and development. In accordance with Silverman's statement (2006: 21), many teacher training programs are not effective; this is because the training does not match the needs of teachers. After completion of the training, many teachers do not apply the results of the training, because the material learned in the training does not match the material needed for performance improvement. 
Teacher Learners' training focused on improving competencies in the still low is the right strategy. Training is not carried out equally for all teachers, but every teacher gets training according to the needs of which competence is still low. Suppose the teacher is still low mastery of his competence in the group of competence (CG) B as can be seen Figure 3, then the teacher is trained with the focus of training on improving the competence B. Similarly, teachers who are still low in CG F, the training followed by the teacher is a training that is focused on increasing the competence of GC F. Thus, the training that teachers participate becomes more targeted than the teacher should attend training that includes all competencies. The policy to encourage teachers to become learners is a strategic step to encourage teachers to develop self-employment in a sustained manner. The development of sustained professionals can encourage teachers to undertake lifelong learning, so that teachers can play the role of mentor responsible for sustained education (Wen \& Wu, 2015). The development of sustained proficiency for each teacher demands the commitment of each teacher (Brine, 2005). The learners' teacher program, which in essence encourages teachers to raise awareness and commitment to continue learning, becomes an appropriate vehicle for sustained teacher self-development. Learners' teacher is a teacher who is committed to continuing to study as long as she devotes herself to education. Therefore, when a teacher decides to quit or does not want to learn, then at that time he stops being a teacher.

The teacher training with an enormous number of targets, such as in Indonesia with teachers to millions, is not a simple task. Complexity increases with Indonesia's vast geographical conditions, spread over thousands of islands. It needs a specific strategy in formulating the training model and also in the implementation of the training itself. If not careful, not only will the training be ineffective, but also risk the need for enormous training funds. Therefore, a module-based training strategy implemented in various modes (online, face-to-face, and face-to-face-online integration) is an excellent training strategy. Most of the teacher trainings have only been done face-to-face, while online teacher training is relatively rare. Teachers training with very large and geographically scattered goals in different areas are difficult to rely solely on face-to-face training. In addition to the large costs, online training also requires a lot of effort in the implementation. Online and face-to-face online trainings are the right solutions for the condition. Web-based online training model provides convenience for customers who have limited time and difficult to reach the training location (Prasetyo \& Gintoro, 2010). The ICTs can empower and help facilitate greater access to the development of sustained education for marginalized people (Makrakis \& Kostoulas, 2012, p. 9). Thus, the training of learners' teachers who also use the online way can cover how much the number of target teachers scattered throughout the territory of Indonesia.

The education for sustained development does not merely concentrate on providing knowledge, but also seeking solutions to everyday life situations (Briede, 2016, p. 34). This requires teachers to increase capacity in taking responsibility for strategic roles in the classroom. The continuing teacher, who continues to improve self-competence, becomes an important instrument for conducting learning in a quality classroom. Learning in this well-executed classroom will be the best vehicle for every student in improving the learning level. At the end, a new generation of more knowledgeable scientists will encourage better human life. The teacher faces new challenges and changes in education and is important for teachers to equip themselves with new knowledge and skills (Kabadayi, 2016: 12). Teachers are required to continue learning as well, because the teacher's role 
continues to grow, not only transmitting knowledge to the students, but also inspiring and guiding students as a learner (Bell, 2016, p. 52). Their role is to inspire and guide their students as learners. Education is not about filling a bucket but about lighting a fire. The awareness rising on the important role of teachers has implications for the higher demands on teacher quality. The use of teacher competency test results for the basic development of the teacher's competence improvement program is a major breakthrough in the development and development of the teacher profession. During this time many teacher quality improvement programs implemented are based only on qualitative and speculative analysis of decision makers without being based on accurate data. Non-data-based teacher training programs are vulnerable to program nonconformity with real needs, so that programs implemented cannot deliver optimal results.

\section{Conclusion}

The teacher competence test in Indonesia is conducted on teachers throughout Indonesia, on all subjects, at all levels of schools, as a vehicle to obtain teacher competency map data. The tests are conducted online and offline using multiple choice tests, which are used to measure pedagogical and professional competence, according to teacher competency standards, which the government has set. The teacher competency test is an important breakthrough in: 1) mapping teacher competence with wide scope (nationally), and 2) utilization as the basis for determining teacher professional development program. The test result provides teacher competency profile, both nationally, regionally, and individual teacher, serve as the basis for preparation of teacher competency improvement program. Programs of teacher professional development which conducted based on the valid data is effective to encourage the Sustainable Profession Development. The Learners' Teacher Competency Enhancement Program (LTCEP), in addition to improving the competence of teachers based on low competence on the competence profile of the competency test results that have been done, can also encourage teachers to be someone who continues to learn. A learners' teacher is a prerequisite for the realization of a sustained educational system. Learners' teacher continues to update the competencies according to the needs and development of science, so that students can facilitate creatively and be able to inspire every student to become a lifelong learner. The new generation generated by learners' teachers is a sustained generation of sustained human development buffers.

\section{References}

Acquah, P. C., Frimpong, E. B., \& Borkloe, J. K. (2017). The Competency Based Training (CBT) concept of teaching and learning in the Technical Universities in Ghana: Challenges and the Way Forward. Asia Pacific Journal of Contemporary Education and Communcation Technology, 3(2), 172-182.

Anthony, G. \& Walshaw, M. 2009. Characteristics of Effective Teaching of Mathematics: A View from the West. Journal of Mathematics Education, 2(2), 47-164.

Baumert, J., \& Kunter, M. (2006). The COACTIV model of teachers' professional competence. Jerman: Center for Educational Research, Max Planck Institute for Human Development. 
Bell, D. (2016). Twenty first century education: transformative education for sustainability and responsible citizenship. Journal of Teacher Education for Sustainability, $18(1), 48-56$.

Briede, L. (2016). The relationship between mathematics teachersk teaching approaches and 9th grade students' mathematics Self. Journal of Teacher Education for Sustainability, 18(1), 34-47.

Brine, A. (2005). Continuing Professional Development: A guide for information professionals. Great Britain: Chandos Publishing.

Carreker, S., \& Boulware, R. (2015). The personal competencies through the eyes of the classroom teacher. Center on Innovations in Learning, Temple University, Philadelphia, PA.

Darling, L., \& Hammond. (2010). Evaluating teacher effectiveness: how teacher performance assessments can measure and improve teaching. Washington: Center for American Progress.

Directorate of Teachers and Education Personnel. (2015). Technical guidance on improving the competence of the learner teachers. Jakarta.

Directorate of Teachers and Education Personnel. (2015). The Strategic Plan of the Directorate of Teachers and Education Personnel 2015-2019. Jakarta.

Directorate of Teachers and Education Personnel. (2016). Guidelines for teachers training by face-to-face (offline), online, and combination mode. Jakarta.

Donaldson, G., et al. (2013). Teaching profession for the 21st century. Belgrade: Centre for Education Policy Svetozara Markovica 22/20.

Goldstein, I. L., \& Ford, J. K. (2002). Training in organizations: need assessment, development, and evaluation. Belmont: Wadswoorth Group.

Hasanah, D. S. (2010). Pengaruh pendidikan latihan (diklat) kepemimpinan guru dan iklim kerja terhadap kinerja guru sekolah dasar se-Kecamatan Babakancikao Kabupaten Purwakarta. Jurnal Penelitian Pendidikan, 11(2), 85-96.

Hattie, J. (2003). Teachers make a difference: What is the research evidence?. Paper was presented in Australian Courcil for Educational Research Annual Conference on Building Teacher Quality, in University of Auckland.

Hospesová \& Tichá, M. (2000). Developing mathematics teacher's competence. Research report supported by the Socrates Comenius project 87636-CP-1-2000-1-CZComenius-C31 and GACR 406/02/0829 and 406/05/2444.

Iswari, O. M. (2009). Membina perkembangan emosi remaja meningkatkan profesional guru. PEDAGOG Y: Jurnal Ilmiah Ilmu Pendidikan, 9(1), 101-112.

Kabadayi, A. I. (2016). A suggested in-service training model based on turkish preschool teachersk, conceptions for sustainable development. Journal of Teacher Education for Sustainability, 18(1), 5-15.

Kementerian Pendidikan dan Kebudayaan. (2015). Pedoman pelaksanaan uji kompetensi. Jakarta: Direktorat Guru dan Tenaga Kependidikan.

Kementerian Pendidikan dan Kebudayaan. 2016. Buku 1 pembinaan dan pengembangan profesi guru. Jakarta: Direktorat Guru dan Tenaga Kependidikan.

Kunartinah \& Sukoco, F. (2010). Pengaruh pendidikan dan pelatihan, pembelajaran organisasi terhadap kinerja dengan kompetensi sebagai mediasi. Jurnal Bisnis dan Ekonomi (JBE), 17(1), 74-84. 
Makrakis, V., Kostoulas, N., \& Makrakis. (2012). Course curricular design and development of the M. SC. programme in the field of ICT in education for sustainable development. Journal of Teacher Education for Sustainability, 14(2), 5-40.

Ministry of Education and Culture. (2015). Guidelines for the implementation of the competency test. Jakarta: Directorate of Teachers and Education Personnel.

Ministry of Education and Culture. 2016. Book 1 Continuous professional development of teachers. Jakarta: Directorate of Teachers and Education Personnel.

Mulyasa. (2007). Standar kompetensi dan sertifikasi guru. Bandung: Remaja Rosdakarya.

Mulyasa. (2013). Uji kompetensi guru dan penilaian kinerja guru. Bandung: Remaja Rosdakarya Offset.

OECD. (2009). Teacher evaluation: a conceptual framework and examples of country practices. Paper was prepared for presentation at the OECD-Mexico Workshop Towards a Teacher Evaluation Framework in Mexico: International Practices, Criteria and Mechanisms, Mexico City.

Okeke, C. I., \& Mtyuda, P. N. (2017). Teacher job dissatisfaction: implications for teacher sustainability and social transformation. Journal of Teacher Education for Sustainability, 19(1), 54-68.

Prasetyo, T. I., \& Gintoro. (2010). Pengembangan model pelatihan online berbasis web untuk keunggulan bersaing pada PT Intellisys Tripratama. Jurnal CommIT, 4(2), 109-119.

Redding, S. (2014). Personal Competencies in Personalized Learning. Center on Innovations in Learning, Temple University.

Roelofs, E., \& Sanders, P. (2007). Towards a framework for assessing teacher competence. European journal of vocational training, 40(1), 123-139.

Silberman, M. (2006). Active learning: a handbook of techniques, designs, case examples, and tips. San Francisco: Pleiffer.

Vathanophas, V. (2007). Competency requirements for effective job performance in Thai public sector. Contemporary management research, 3(1), 45.

Vermunt, J. D., \& Verloop, N., (1999). Congruence and friction between learning and teaching. Learning and instruction, 9(3), 257-280.

Wen, Y., \& Wu, J. (2015). A study on Singapore Chinese language teachers' professional proficiency and training needs for sustainable development. Journal of Teacher Education for Sustainability, 19(2), 69-89.

Wilkerson, J. R., \& Lang, W. S. (2007). Assessing teacher competency: five standardsbased steps to valid measurement using the CAATS model. United States: Corwin Press.

Zineb, et al. (2017). The application of the competency-based approach to assess the training and employment adequacy problem. International Journal of Education (IJE), 5(1), 1-18.

Correspondence concerning this paper should be addressed to Tutut Herawan, Universitas Teknologi Yogyakarta, Kampus 1 Ring road utara, Jombor, Sleman, Yogyakarta, Indonesia 55285. Email: tututherawan@uny.ac.id 